\title{
Impact of critical illness news on the family: hermeneutic phenomenological study
}

\author{
Impacto da notícia de doença-crítica na vivência da família: estudo fenomenológico hermenêutico
} Impacto de la noticia de enfermedad-crítica en la vivencia de la familia: estudio fenomenológico hermenéutico

\section{Anabela Pereira Mendes',11}

'Escola Superior de Enfermagem de Lisboa, Unit for Research and Development in Nursing. Lisbon, Portugal. "Universidade Católica Portuguesa, Institute of Health Sciences, PhD in Nursing. Lisbon, Portugal.

How to cite this article:

Mendes AP. Impact of critical illness news on the family: hermeneutic phenomenological study. Rev Bras Enferm [Internet]. 2018;71(1):170-7. DOI: http://dx.doi.org/10.1590/0034-7167-2016-0163

\author{
Submission: 05-17-2016 Approval: 01-20-2017
}

\begin{abstract}
Objective: Understand the impact of critical-illness news on the experience of family members at an Intensive Care Unit. Method: Phenomenological approach according to Van Manen's method. Open interviews were held with 21 family members. From analysis and interpretation of the data, three essential themes were identified: the unexpected; the pronouncement of death; and the impact on self-caring within the family. The study complied with the ethical principles inherent to research involving humans. Results: The unexpected news and death of the sick person influence the well-being and self-care of family members, affecting their ability for analysis and decision making. It was observed that the family experiences the news with suffering, mainly due to the anticipation arising from the events. Final considerations: The humanity of nurses was revealed in response to the needs of the family. In view of the requirements for information, it was verified that the information transmitted allowed them to become aware of themselves, to become empowered in their daily lives and to alleviate the emotional burden experienced.
\end{abstract}

Descriptors: Family; Intensive therapy; Nursing; Information; Life-Changing Events.

\section{RESUMO}

Objetivo: Compreender o impacto da notícia de doença-critica na experiência vivida pelas pessoas da família numa Unidade de Cuidados Intensivos. Método: Abordagem fenomenológica segundo Van Manen. Realizaram-se entrevistas abertas a 21 pessoas da família. Na análise e interpretação dos dados identificaram-se três temas essenciais: o inesperado; o prenúncio de morte; o impacto no cuidar de si. O estudo cumpriu os princípios éticos que lhe são inerentes. Resultado: O inesperado da notícia e a possibilidade de morte da pessoa doente influenciam o bem-estar e o autocuidado das pessoas da família, condicionando a sua capacidade de análise e decisão. Constatou-se que a família vive a notícia com sofrimento, principalmente pela antecipação que faz dos acontecimentos. Considerações finais: A humanidade dos enfermeiros revelou-se na resposta às necessidades da família. Face à necessidade de informação, verificou-se que a informação transmitida Ihes permitiu, consciencializarem-se, capacitarem-se no quotidiano e aliviar a carga emocional experienciada.

Descritores: Família; Terapia Intensiva; Enfermagem; Informação; Acontecimentos que Mudam a Vida.

\section{RESUMEN}

Objetivo: Comprender el impacto de la noticia de enfermedad-crítica en la experiencia vivida por las personas de la familia en una Unidad de Cuidados Intensivos. Método: Abordaje fenomenológico según Van Manen. Se realizó entrevistas abiertas a 21 personas de la familia. En el análisis e interpretación de los datos se identificó tres temas esenciales: el inesperado; el prenuncio de muerte; el impacto en el cuidar de sí mismo. El estudio cumplió los principios éticos que son inherentes. Resultado: El inesperado de la noticia y la posibilidad de muerte de la persona enferma influencian el bien-estar y el auto cuidado de las personas de la familia, condicionando su capacidad de análisis y decisión. Se constató que la familia vive la noticia con sufrimiento, principalmente por anticipación que hace de los acontecimientos. Consideraciones finales: La humanidad de 
los enfermeros se reveló en la respuesta a las necesidades de la familia. Ante la necesidad de información, se verificó que la información transmitida les permitió, concienciarse, capacitarse en el cotidiano y aliviar la carga emocional experimentada. Descriptores: Familia; Terapia Intensiva; Enfermería; Información; Acontecimientos que Cambian la Vida.

\section{INTRODUCTION}

The critical illness situation with ICU admission is very significant for the family from a physical and emotional point of view $^{(1-3)}$. It can be seen that the vulnerability in which the sick person finds himself is, in a simultaneous and sequential way, also experienced by the family. Thus, everyone is affected; the disease situation is a matter that they wish to exclude, because of the fragility it brings them on an individual and collective basis.

It is observed that the experience of health-disease transition processes is highly charged, due to significant changes found individually, but also in the family dynamics ${ }^{(2-4)}$. They suddenly passed from a daily experience of health and stability to a situation of illness, with all that entails.

From their personal register, as a result of their current or previous experiences, lived or known, they construct a personal understanding of what it means to be critically ill and hospitalized in intensive care. King $^{(5)}$ states that "individuals react to people, events and objects, taking into account their perceptions, their expectations and their needs". The way in which they act is in accordance with "past experiences, and the consciousness of the present emerges from the reading of their future actions"(5). It has been verified that nurses play a strategic supportive role ${ }^{(6)}$. Oliveira and Nunes ${ }^{(7)}$ and Mendes $^{(8)}$ report that the experience of hospitalization of a family member in an ICU requires nurses provide a humanized care rooted in the daily warmth with which the construction of relationships is essential. The present moment is important, but necessarily the future experience and the sequelae that may emerge from it. Knowing that the moment of admission to the hospitalization context, is a major crisis, and the unfamiliar environment of the ICU can condition an effective interaction with the team members ${ }^{(9-10)}$.

In the context of hospitalization the communication that it establishes, between nurses and family, emerges in an explicit or implicit way to the human interaction. Meleis ${ }^{(11)}$ states that human communication is "a process of behavior based on a system of symbol exchange in which meaning is transmitted and interpreted among those who interact". It is hoped that in the interaction with the family, experiencing the process of health-illness transition with one of its members, the nurse will assume through professionalism, given that "professionalism is in the subtlety, in the ability to encounter to make sense of this encounter and then to make progress alongside it"(12).

With the intention of studying the family experience faced with ICU hospitalization, we now intend to analyze one of the most significant phenomena, namely "The impact of the news" and the essential themes that characterize this. The purpose of the present study is to determine, from a perspective of Meleis ${ }^{(4)}$, how nurses influenced the experience of family members within the possibility of an interaction which is known to exist.

\section{METHOD}

\section{Ethical aspects}

It was ensured that the decision to participate in the study was based on the provision of detailed and consistent information, considering the possibility of being clarified and valid. The possibility of leaving the study at any time was clear, if that was the decision of the person. This guarantees the autonomy of the participant. The term of consent to participate in the study, which was signed by the participant, was whenever possible made available previously, in the sense of understanding it and deciding in a comfortable way.

It was considered in the scheduling of the time and place, the availability of the participant and the possibility to conveniently make an audio recording. During the interview, the vulnerability of the person was respected, with the researcher adopting an attentive and responsible position regarding their tone of voice and posture. This reveals in the researcher an ethical sensitivity. The confidentiality and anonymity of the participants was guaranteed by coding each of the discourses from 1 to 21 preceded by FM (Family Member).

In situations where it was known that the hospitalized person died, the proposal of Lautrette et al. ${ }^{(17)}$ was considered. in which the interview took place only after 90 days. It was important for the person in the family to find stability, in the face of the suffering experienced, that would allow the intentional revisiting of the lived experience.

In the ethical assessment of the investigation procedures, it was assured and verified by the responsible entity that the study complied with the ethical principles related to such research.

\section{Type of study}

Considering the purpose of the study, it was found that it fit into a qualitative paradigm.

\section{Theoretical-methodological reference}

It was decided to adopt the phenomenological hermeneutic approach according to the method of Van Manen ${ }^{(13)}$, considering the intention to know the experience lived by the family. This author leaves the researchers the responsibility to tacitly define the interest of the study and that its analysis and interpretation is always sustained in what the data say and not in a previously existing theoretical construct. The requirement of systematic reading and a constant exercise of writing and rewriting for textual construction are also required. According to Van Manen: ${ }^{(13)}$

The purpose of phenomenology is to transform lived experience into a textual expression of its essence ... the text is at the same time a reflexive revival and reflective appropriation of something meaningful: a concept by which the reader is powerfully animated in his or her lived experience. 
Honoré(14) understands "to have experience" or "to preserve in me, not only the information and meanings related to situations, people, things, but also the memory of the meaning that it had for me at a certain moment and in particular circumstances". He adds that meaning "is the way I perceived what was happening"(14).

\section{Methodological procedures}

The data collection was performed by an interview with open questions, as suggested by van Manen ${ }^{(13)}$. It was proposed that the interview should be based on "an open, exploratory question, and subsequent questions or interventions by the researcher should emerge from the flow of descriptions from the participants"(15).

\section{Data source}

Twenty-one interviews were conducted with individual adult family members of an adult person who was admitted to an ICU. The mean duration of the interviews was 60 minutes and they were held at a place suggested by the participant, with the family's home being the most frequent. Exclusion criteria were: age of the participant (if less than 18 years); age of the patient (if less than 18 years old); and physical or emotional instability of the family member.

\section{Collection and organization of data}

The following participants were referenced in different ways into a "snowball", mainly by the previous participant and other members of the family. Permission was requested to record the interview and a verbatim transcript was made.

\section{Data analysis}

The use of $\mathrm{NVivo} 8^{\circledR}$ software in the organization and analysis of the data was considered fundamental, given its extension. The interviews assumed a record of conversation, with the intention of allowing the participants to freely revisit their lived experience. The descriptive narrative, which resulted, was "the basis for a structural and reflective analysis, creating a portrait of the essence of the experience"(16). The lived experience is thus "the breath of meaning [...] has a certain essence, a 'quality' which we recognize in the retrospection"(13). The goal will always be "to reach the meaning of experience, that is, what the experience means to the people who have had the experience in question and who are therefore apt to give a comprehensive description of the same"(16).

\section{RESULTS}

It was verified from the analysis and interpretation realized that in the experience lived by the family, the knowledge of the disease situation was then the inaugural moment that triggered a whole experience that ensued. In this area, three essential themes were identified: the unexpected; the pronouncement of death; and the impact on self-caring. They showed what the news meant to the family from a cognitive and emotional point of view, and the repercussions of the news itself - in their caring (Figure 1). It can be seen that each one of these subjects assumes a distinct place in the experience, but they have a cumulative effect with each other.

It is now intended to work on each of the essential themes, in detail, considering the narrative of the participants who support them and the phenomenological approach in which it is inserted. It seeks to characterize the phenomenon under study, i.e. how the family experienced the arrival of the news.

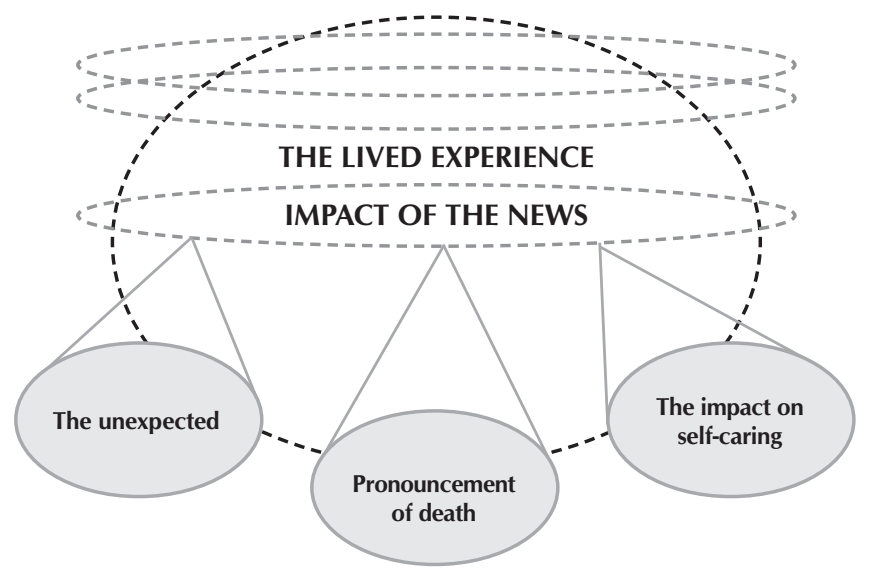

Figure 1 - The news: how it arrives and affects daily life

\section{The unexpected}

The people in the family through their discourse revealed that in the daily routine the news of critical illness of one of its members had compromised their daily lives. They refer to the present moment, but also to an immediate anticipation of what awaits them in the future moment.

They perceive that the news, in that which it contained of possible understanding, translated above all into a reality that they admittedly knew to exist, but that they did not want to admit. They reveal in an abrupt way the emotions they experience, leaving them physically weak, fragile, and vulnerable. The surprise proved dramatic, in a lack of peace, a shock difficult to tolerate. As the people in the family state:

... to receive a call ... my mother was hit, seriously injured, between life and death, had a cardiac arrest ... a total despair ... I could not speak or cry. (FM2)

... when the doctor called me and told me she could last only that night ... the news caught me by surprise, I was shocked. (FM16)

... a lack of peace. The unknown ... How would tomorrow be? It was not knowing if there was a tomorrow. It is living the second, the moment. (FM19)

They know the person by their individual and unique characteristics, with whom they have constructed a life process and are now faced with their absence in life activities. Looking at them with a technical support they do not understand, yet they know supports their fragile physical ability, proves to be frightening and dramatic. They perceive that the information that arrives helps gradually to draw a picture that they discover 
to be ugly and sad. They feel that the clinical condition of their family member is unstable and that their family tends to compromise, considering the impact felt and continuous.

It was a shock because he was in a glass room, isolated from other people, with many machines, with many tubes everywhere, including one of them, coming out of a lung. It was a shock to see him like that ... suddenly that was it! (FM20)

They found that it was difficult to control and manage emotions. The experience of the situation tended to exceed their habitual capacity of response, they felt helpless, unable to resist and to establish what to do, how to do it and when. They felt vulnerable considering the condition of the sick person and the context in which everything happens, in which the unknown and the limited access are determining and central factors.

... the person feels helpless, to be there close by, look at the other person and to be helpless. (FM11)

... I was in shock. The doctor asked me several times if I was able to leave. I thought I was a strong person. I went out in the car and drove around ... (FM16)

It is verified that they revisit in constant instability the eminence of the sick person's death. They feel that these two contexts are always very close and intimately possible.

\section{The pronouncement of death}

Add to the critical illness the possibility of no return, of not restoring continuity in the daily life, hitherto known. In the eminence of finitude, the end of life process, they felt an overwhelming sadness that compromised the capacity to interact, to assume this possibility with other people in the family. It is verified that proximity, the bond between family member and sick person significantly influences the experience, it is considered the reference to the partner, the husband, the child.

... when I heard it, it was a terror, it was so bad, so bad, so bad, I did not want to share it with anyone, my husband's family, nor my family. I did not want to think he could die in a few days ... lose my companion. (FM8)

The information, when transmitted in a timely manner and of perceivable content, assumed an important meaning in the experience, enabling an understanding of the events. However, they realize that, even though understanding occurs, discouragement and anxiety can be alleviated, but rarely disappear. They feel incapable of managing the impossibility of doing something that could reverse the situation, of caring for their relative.

... he called me aside and said that he had to be intubated ... he explained to me that he had lung cancer, he had no chance at all ... things are so weird, very sad, because we cannot do anything ... (FM11)

They returned systematically to a frightening possibility of never interacting again, of not being able to share moments of life in common. The vulnerability experienced shows that, for the information they had, combined to that related to an ever present imagination. They constructed in their daily lives the possibility of events happening abruptly, to add to their suffering.

\begin{abstract}
The fear that she would not see me again, the fear that she would not recognize me, the fear of losing her ... I still have the image of her eyes ... it was not my mother, she was not there ... (FM14)

... I only thought about my wife who might not be here the next morning! (FM16)
\end{abstract}

\section{The impact on self-caring}

Dealing with the situation proved to be distressing and deprived them of the usual initiative to take care of themselves. They did not express or feel any concern with the activities of eating, resting and sleeping or personal hygiene and comfort. They considered that the anguish experienced took away the possibility of action, communication and decision making.

... I did not want to eat, I did not want anything, they would fetch me hot chocolate, they would get things ... after two in the morning they told me to go rest, go to the hotel, I did not sleep, I could not, I turned, turned, turned... it was six, seven o'clock, I went there again to know the news ... (FM1)

This alienation from caring for oneself resulted from missing the patient and their absence in daily life, usual activities, but also from the fact that they were often not received into the unit and integrated into the decision making and care of the sick person. They assumed that caring for the sick person was essential, but that it was important to consider the family in that person's life. They felt that such a situation was acceptable at the most critical moments, such as admission, but that progressively tended to be stigmatizing.

... they do things as if we are not there, ends up being a little distant ... they should have a little more calm, of attention, because the relatives are suffering, the people are there sometimes God knows how and they should think ... ( FM11)

... I think nurses and doctors are there to treat the sick, but the family also has needs. It must be another nurse without a work shift ... (FM12)

They listened, among all members of the family, those who could feel more fragile and vulnerable, with the news and the experience of this. They knew it mattered to know what to tell them and when to tell them. The information they acquired, knowing it to be very negative, was filtered in the sense of not causing very significant damage to these people in the family. They referred in particular to their descendants and the elders, who were now dealing with a child or grandson in a situation of critical illness.

... my in-laws are already old people and it would be a great risk to tell them the truth ... I told my sister-in-law to warn the brothers and parents calmly so that the parents could know. (FM1) 
I got home about 3:00 in the morning and they were asleep. How was I going to tell my kids that their mother was "by a thread"? Just as the doctor had told me "just a miracle". No miracle, this is for those who believe. She was all contaminated. (FM16)

... I also have to go with my mother-in-law, who is her mother and her mother wants to go to the hospital, wants to see, wants to be there, it is not ... who gives support? (FM9)

In a progressive way, they find that the situation of illness and hypothesis of threat to life compromised the caring for oneself, but that cyclically the absence of self-care compromised the experience with the news, with the information that came to them in different forms and ways (Figure 2). Knowing that at each moment, present and future, their calm and sustained presence would be support for themselves, but also, and fundamentally, for the sick person and other members of the family who they knew were more vulnerable.

\section{DISCUSSION}

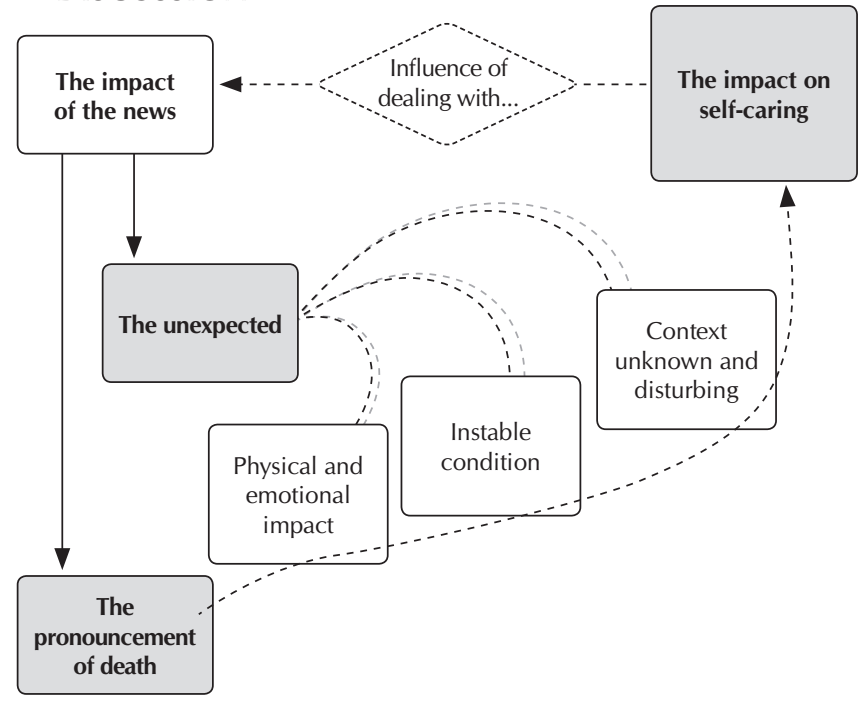

Figure 2 - Impact of the news on self-care: The inter-relationship they create

It is verified that the lived experience of the family reveals peculiarities of enormous suffering. It is known, according to some authors, that when continued and intense, it can result in important emotional, psychosocial and structural changes in the individual and family domain ${ }^{(8,18-19)}$. It has been found that two key determinants contributed to this experience, namely the fact that it is unpredictable and associated with the idea of threating the life of the person now hospitalized. This presentation or register generates uncertainty and shock, with the experience of intense and significantly penalizing emotions ${ }^{(20)}$.

It is noted that, in addition to the condition of the sick person, the context in which hospitalization occurred was also significant. These results are similar to other studies that report on the context, a very negative matrix with a very significant influence on the family members ${ }^{(1,3)}$.
The family realizes that in this context of hospitalization, compared to others they know, the physical stability of the people in the hospital is highly compromised and that many of the situations end in death. This is always associated with physical frailty and mechanical support that supports and enables vital functions. In the need for constant intervention and monitoring, the access allowed is far from that expected. It is verified that this perception of the family is echoed in the scientific evidence produced, and three indicators are related to the context: the statistical indices associated with these contexts reveal high rates of mortality and morbidity; everything is highly instrumented and unknown; and access to the unit and the sick person is very restricted ${ }^{(9,21)}$.

They find in the perception of instability and threat to life an extreme need for immediate information. They considered that the possibility of being informed proved very significant, positive or negatively, according to the response found to their needs ${ }^{(8,22)}$. It is shown to be a period lived with great emotional instability faced with the associated uncertainty. They report in detail the need to know what is happening with the patient and what is intended to be done ${ }^{(3)}$.

It was found that the family is insistently seeking information in the internal and external support to the unit that allows them to progressively learn to deal with the facts and with the resulting emotions. According to some authors, they seek to prepare themselves to deal with the situation and to be comforted ${ }^{(1-2,23-24)}$.

From the above, it is observed that in the initial period of great uncertainty, the difficulty in absorbing information is very significant. It is important to understand this initial shock in the process and to consider a space of time, in the sense of allowing the family to stabilize. Identification, if possible at admission, of the information needs of the family members, and the possible responses of the care staff, makes it possible to maintain the bond with the sick family member, but also with the team that takes care of him or her. It involves a sharing of facts, language and requires the involvement of both parties.

They assumed the need to know, to be informed, but also to be comforted and protected, the existence of multiple sources, referring to the context of unity, but also to all the means that enabled some understanding of the evolution of the situation. In the context of hospitalization, the initial concern of the family focuses on the evolution of the situation and the care that the team has with their relative. It is found that he is resigned to waiting, with more or less tolerance, receiving the first information at the moment when he has access to the unit ${ }^{(25)}$. He intends through the continuous presence to unveil the prognosis and to understand the situation as soon as possible $\mathrm{e}^{(9)}$. The family stresses that the need for information addresses the present and what is expected in the near future ${ }^{(22)}$.

The possibility of interaction and the involvement achieved, with the nurses, proved to be essential. From the perspective of Meleis et al. ${ }^{(4)}$, nurses prove themselves, whenever they respond competently and professionally, to be facilitators in the ongoing transition process. Khalaila ${ }^{(23)}$ found that nurses developed strategies to involve family members in the dynamics of care in order to prepare them and alleviate the negative emotional burden experienced. He verified that from the perspective of the relatives, 
the nurses' support allowed them to adjust to the situation, to relieve the tension experienced and to feel protected ${ }^{(23)}$.

It was of significant relevance for the family members how the news was given to them and how the team members were preparing to update the information and answer the family's questions. Professionalism was revealed in the way they transmitted the initial information and in how they cautioned their reception. The sensitivity of the professionals left in each family member a very positive meaning of living. Participants in the study by Wahlin et al. ${ }^{(2)}$ felt that everyone was involved in the care setting where they received continuous, direct and honest information that allowed room for hope. These family members point out that the way they were received and the sensitive and human manner while they were informed was meaningful to the family. They equally emphasized the information and discussion regarding the diagnostic and therapeutic interventions observed in the care of their family member in the $\mathrm{ICU}^{(2)}$.

The way in which the situation has affected the family and each member allows us to perceive the fragility found through the absence of the sick person in the daily life. They were seen to function in a matrix of reciprocity in which they feel and offer warmth ${ }^{(8)}$. They experience vulnerability and gradually find capacity for everyday life ${ }^{(8)}$. The people they spoke to sought to react and deal with adversity to develop or strengthen existing family ties, functioning as a shared and constructed support that also contemplated the sick person. Wahlin et al. ${ }^{(2)}$ found that the union achieved among family members was assumed to be essential. They point out that if they are constituted as a unit - the family - it confers the capacity to withstand the emotional disturbance and suffering that results from the experience of critical illness ${ }^{(2)}$. Mendes ${ }^{(8)}$ points out that it is in the family structure that "he will probably ask for comfort and seek to quieten his revolt". The family has that which Alarcão ${ }^{(26)}$ denominates a "retroaction", which can be negative or positive. The author states that negative feedback acts in a "self-corrective" manner in order to maintain the desired stability of the system ${ }^{(26)}$. It seeks to correct "the effect of internal or external factors to the system, that could change its equilibrium"(26). Positive feedback "introduces into the functioning of the system, the notion of qualitative change, enabling it to grow and to be creative"(26). However, according to Meleis ${ }^{(11)}$, in response and adaptation processes, "the changes that have occurred and those that are occurring in the structure of families and communities can compromise the role of each of the actors".

It was verified that the constant experience with the situation contributed significantly to impede self-care. They point out that the centrality given to the sick person and to everything that involved them tended to leave to the background those activities that related themselves. They systematically set aside all activities aimed at self-care. This intervention contemplates the existence of a "someone", of an "agent", who has the role of caring ${ }^{(27)}$. The term agent is used in the sense of defining the person who takes charge of the action. Self-care, according to Orem ${ }^{(27)}$ is a maturation activity of people who develop abilities to take care of themselves, in their situational contexts. It considers self-care as a set of activities initiated and performed by the individual, family or community, for their own benefit to maintain life, health and well-being ${ }^{(27)}$. It was found that, although certain members of the family deferred their own personal care, they considered in the context of the family those who were most vulnerable, pondering the lived experience and internal resources of the subject.

It was found that, progressively, the internal support of the care team, but also outside the family, have played a very significant role in empowerment or possibility of adaptation. The internal and external resources are fundamental to deal with the situation of ICU admission, in that empowerment was closely related to the trust, humanity and professionalism that they found in health professionals ${ }^{(8,18)}$.

Based on the above and on an observation by Meleis et al. ${ }^{(4)}$, namely that the process may involve more than one person and is embedded in the context and in the situation, it is recommended to consider the entire care process, from the data collection to evaluation of interventions, and the family in which the now sick person belongs; thus promoting the humanization of care, according to the guidelines inherent to the professional practice of nurses. Relvas ${ }^{(28)}$ from a psychological perspective of intervention with families, states that working with the family "implies understanding the present moment they are living, but also revisiting their own individual and family history". He adds that "in interaction with the family, communication is assumed as the central vector in the construction and transformation of relationships"(28).

The needs they encounter and the expectations they place on the interaction with professionals will depend substantially on the initial moments, what is proposed to them and that which they acquire in the context of care, knowing that they are constantly moving in the acquisition of updated and comprehensible information. The possibility of knowing what is to be expected allows you to predictably prepare and adapt. They found that 'not knowing' conferred a penalizing and dramatic meaning within the experience.

\section{Limitations of the study}

We are aware that the options followed in this study do not allow the traditional generalization of results, since the experience is personal and private. However, according to the author of the methodological reference used in this study, the possibility of transferability belongs to the readers, knowing that it may have implications for the practice of care in contexts with similar characteristics.

\section{Implication of results for practice, pre- and post-graduate training, and future research}

It is proposed that the nurses in their clinical practice should assume as fundamental the daily reception of the family, this necessarily reducing the need for the family to go in search of the nurses. It is important that the reception, due to the scientifically constructed proximity, makes possible an early diagnosis of states of unrest, as a result of the experience of poorly clarified scenarios. It is known from the data that enlightenment by the acquisition and appropriation of information comforts and appeases the family. This matrix of action must be considered in the training plans, ensuring that current and future nurses learn to structure 
the intervention - the reception, question the effective response to the needs of the people and guarantee, by oral and written means, the possibility of continuity in care. It is proposed that the intervention - the reception, is investigated exhaustively by other researchers, in a qualitative or quantitative model, having as participants each of those involved in the therapeutic triangle. We are currently working with postgraduate students, especially in specialization in person for the critical situation, in which this intervention - the reception of the family client, is analyzed theoretically and technically.

\section{FINAL CONSIDERATIONS}

It was verified from the participants' report that in the lived experience the impact of the news was assumed as a very significant moment. The daily life they knew reveals itself from one to another frightening and dramatic moment in which everything is unknown and lacking constant preparation. The news that comes from multiple sources allows by the content to anticipate what is to come. It leaves them the certainty that the person in the now hospitalized family is critically ill, but infers the possibility of death.

With the intention of understanding they resort to multiple sources, in the context of hospitalization, but also in the circle of contacts that they have externally, they recognize that even if it is scarce, and far from that hoped for, this information allows them a more stable experience, when compared to moments marked by a total lack of information.

Moments that, because of the significant repercussions on their well-being, impaired their habitual ability to respond, they progressively stopped attending to their need to eat and to rest, considering that their focus was the currently sick family member and that their personal self-care had been relegated to a secondary position at that moment.

They look for a constant and close interaction with the nurses, who know how to assume the care for their family member, to find the information they need, but also for the necessary comfort to understand how to manage and learn to deal with the situation. They recognize how the information is transmitted to them and the content provided by the nurse and how they propose to respond to their needs.

In advanced nursing practice it is considered that the nurses assume a central role here, considering they are qualified, ready to respond to the real and potential needs of the people with whom they interact.

It is clear from the data that the experience of a healthillness transition process compromises each one of the participants, knowing that the family counts on the nurses' competence in the care of their family member, but also to consider them in the now sick person's life. Although they understand the central position given by everyone to the sick person, they show that the suffering the family members experience also requires specific attention from the nurses. It was demonstrated that this was where most of their expectations resided.

This study intends to strengthen the critical thinking of nurses and decision making regarding their action, in the constant and constructed interaction with the client and family. Nurses should be aware that the circumstances and context of care, being unknown and of disturbing significance, creates anxiety and demands the family to simultaneously dive and abruptly find strategies to survive and adapt. It is important to ensure that in the interaction with these people, who become nursing clients, their well-being is ensured at every moment, with a detailed knowledge of what causes their anxiety, what they do not want, what they do not intend, knowing that the resources and strategies that they understand and master have often become insufficient. In this register, it is considered essential to ensure that the reception is a daily intervention for nurses, based on a detailed observation of the verbal and non-verbal language of each of the family members. It is underscored that the possibility of influencing positively their experience, in this process of transition, in a singular and plural register, derives from this pre-occupation.

\section{REFERENCES}

1. Nelms TP, Eggenberger SK. The essence of the family critical illness experience and nurse-family meetings. JFN [Internet]. 2010 [cited 2016 Apr 2];16(4):462-86. Available from: http://journals.sagepub.com/doi/pdf/10.1177/1074840710386608

2. Wahlin I, Ek AC, Idvall E. Empowerment from the perspective of next of kin in intensive care. JCN [Internet]. 2009 [cited 2016 Apr 2];18:2580-87. Available from: http://dx.doi.org/10.1111/j.1365-2702.2008.02744.x

3. Santos L, Valois H, Santos S. Aplicabilidade de modelo teórico a famílias de crianças com doença crônica em cuidados intensivos. Rev Bras Enferm [Internet]. 2014 [cited 2015 Oct 21];67(2):187-94. Available from: http://www.scielo.br/pdf/reben/v67n2/00347167-reben-67-02-0187.pdf

4. Meleis Al, Sawyer LM, Im EO, Messias DKH, Schumacher K. Experiencing Transitions: an emerging middle-range theory. Adv Nurs Sci [Internet]. 2000 [cited 2016 Mar 2];23(1):12-28. Available from: https://dx.doi.org/10.1097/00012272-200009000-00006

5. King I. Enfermaria como profesión: filosofia, principios y objetivos. México: Editorial Limusa; 1984.

6. McKiernan M, McCarthy G. Family members' lived experience in the intensive care unit: a phemenological study. Intensive Crit Care Nurs [Internet]. 2010 [cited 2016 March 8];26(5):254-61. Available from: http://dx.doi.org/10.1016/j.iccn.2010.06.004/

7. Oliveira C, Nunes E. Caring for family members in the ICU: challenges faced by nurses in the interpersonal praxis of user embracement. Texto Contexto Enferm [Internet]. 2014 [cited 2015 Oct 21];23(4):954-63. Available from: http://www.scielo.br/ pdf/tce/v23n4/0104-0707-tce-23-04-00954.pdf 
8. Mendes A. A informação à família na unidade de cuidados intensivos: desalojar o desassossego que vive em si. Lisboa: Lusodidacta; 2015.

9. Santiago C, Lazara L, Jiangc, D. A survey of the attitudes and perceptions of multidisciplinary team members towards family presence at bedside rounds in the intensive care unit. Intensive Crit Care Nurs [Internet]. 2014 [cited 2016 Jan 2];30:13-21. Available from: http://www.intensivecriticalcarenursing.com/article/S0964-3397(13)00067-0/pdf

10. Jensen H, Gerritsen R, Koopmans M, Zijlstra J, Curtis J, Ørding H. Families' experiences of intensive care unit quality of care: Development and validation of a European questionnaire (euroQ2). J Crit Care [Internet]. 2015 [cited 2016 Mar 22];30:884-90. Available from: http://dx.doi.org/10.1016/j.jcrc.2015.06.004

11. Meleis A. Role insufficiency and role supplementation: a conceptual framework. Nurs Res [Internet]. 1975 [cited 2016 Mar 13];24(4):264-71. Available from: http://dx.doi.org/10.1097/00006199-197507000-00004

12. Hesbeen W. Cuidar no Hospital. Enquadrar os cuidados de enfermagem numa perspectiva do Cuidar. [trad.] M Ferreira. Lisboa: Lusociência; 2000. [Título original 1997: Prendre soin à l'holital: inscrire le soin infirmier dans une perspective soignante].

13. Van Manen M. Researching lived experience: human science for an action sensitive pedagogy. 2a edição. Ontario: Althouse Press; 1997.

14. Honoré B. Cuidar. Persistir em conjunto na existência. Loures: Lusociência; 2004.

15. Giorgi A, Sousa D. Médodo fenomenológico de investigação em psicologia. Lisboa: Fim de século; 2010.

16. Holanda A. Questões sobre pesquisa qualitativa e pesquisa fenomenológica: análise psicológica Aná Psicol[Internet]. 2006 [cited 2016 Nov 30];3(XXIV):363-72. Available from: http://publicacoes.ispa.pt/publicacoes/index.php/ap/article/view/176/pdf

17. Lautrette A, Darmon M, Megarbane B, Joly L, Chevret S, Adrie C. A Communication strategy and brochure for relatives of patients dying in the ICU. N Engl J Med [Internet]. 2007 [cited 2016 Mar 13];365(5):459-68. Available from: http://www.nejm.org/doi/ pdf/10.1056/NEJMoa063446

18. Mongiovi V, Anjos R, Soares S, Falcão T. [Conceptual reflections on health humanization: conception of nurses from Intensive Care Units]. Rev Bras Enferm [Internet]. 2014[cited 2015 Sep 21];67(2):306-11. Available from: http://dx.doi.org/10.5935/00347167.20140042 Portuguese

19. Radtke J, Tate J, Happ M. Nurses' perceptions of commuinication training in the ICU. Intensive Crit Care Nurs[Internet]. 2012 [cited 2016 Mar 13];28:16-25. Available from: http://dx.doi.org/10.1016/j.iccn.2011.11.005

20. Bernal-Ruiz D, Horta-Buitrago S. Cuidado de enfermería para la familia del paciente crítico desde la teoría de la comprensión facilitada. Enfermería Univ[Internet]. 2014 [cited 2016 Feb 10];11(4):154-63. Available from: http://www.index-f.com/ reu/11pdf/154163.pdf

21. Campos L, Saturno P, Carneiro A. Plano Nacional de Saúde 2011-2016: a qualidade dos cuidados e dos serviços. Lisboa: DGS; 2010.

22. Liu W, Zhu J, Liu J, Guo Q. Psychological state and needs of family member caregivers for victims of traumatic brain injury: a cross-sectional descriptive study. IJNS [Internet]. 2015 [cited 2016 Mar 13];2:231-36. Available from: http://dx.doi.org/10.1016/j. ijnss.2015.07.001

23. Khalaila R. Meeting the needs of patients' families in intensive care units. Nursing standard / RCN Publishing Internet]. 2014 [cited 2016 Sep 30];28(43):37-44. Available from: http://dx.doi.org/10.7748/ns.28.43.37.e8333

24. Simoni R, Silva M. The impact of the visit of nursing on the necessities of the host families of ICU. Rev Esc Enferm USP [Internet]. 2012 [cited 2016 Nov 30];46(Esp):65-70. Available from: http://www.scielo.br/pdf/reeusp/v46nspe/en 10.pdf

25. Trimm D, Sanford J. The process of family waiting during surgery. J Fam Nurs[Internet]. 2010 [cited 2016 Mar 13];16(4):435-61. Available from: http://dx.doi.org/10.1177/1074840710385691

26. Alarcão M. (des)Equilíbrios familiares. Coimbra: Quarteto; 2002.

27. Orem D. Nursing concepts of practice. St. Luis, Missouri: Mosby; 2001.

28. Relvas A. Intervenção sistémica em Portugal. In: S Neves. Psicologia em Portugal. Coimbra: Quarteto; 2003. 